CHARACTERIZATION OF RABIES EXPOSURE IN COLOMBIA, 2007-2011

\author{
Daniel Alejandro Buitrago Medina ${ }^{1}$ \\ Claudia Patricia Roncancio \\ Hugo Grisales \\ Noél Barengo ${ }^{2}$
}

\begin{abstract}
The objective of this study using secondary data from the national health surveillance system was to describe the characteristics of the cases exposed to rabies in the Colombian population during 2007-2011. The cases exposed to rabies were categorized into no-risk exposure, lowrisk exposure and high-risk exposure. An increase in cases exposed to rabies was observed during 2007 (8.7\%) and 2011 (31.5\%). In Casanare, 31.4\% of the cases exposed to rabies were classified as no-risk exposure, whereas in Arauca $86.7 \%$ of the cases corresponded to low-risk exposure cases. Vaupes reported $88.5 \%$ high-risk exposure cases. Rabies exposure was most prevalent in men $(56.3 \%)$ and the population belonging to the subsidized health insurance scheme $(42.2 \%)$. The most common way of transmission was animal bites $(88 \%)$. The observed increase in the number of cases exposed to rabies indicates a need to develop interventions targeting people in high risk exposure regions.
\end{abstract}

Keywords: bites; surveillance; rabies; control and prevention; transmission; Colombia.

\title{
CARACTERIZAÇÃO DA EXPOSIÇÃO A RAIVA NA COLÔMBIA, 2007-2011
}

\section{RESUMO}

Foi realizado um estudo descritivo tipo série de casos utilizando dados secundários do Sistema Nacional de Vigilância Epidemiológica. Foram descritas as características das exposições a raiva na população colombiana durante 2007-2011. Os casos da exposição a raiva observados foram categorizados em a exposição sem risco, a exposição de baixo risco e a exposição de alto risco. Observou-se um aumento dos casos da exposição a raiva de 2007 $(8,7 \%)$ a $2011(31,5 \%)$. Em departamento Casanare, 31,4\% dos casos expostos à raiva foram classificados como exposição sem risco; Arauca 86,7\% dos casos corresponderam a casos de exposição de baixo risco, enquanto Vaupes $88,5 \%$ de casos tiveram exposição de alto risco. A exposição à raiva foi mais prevalente em homens $(56,3 \%)$ e em pessoas pertencentes ao regime de seguro de saúde subsidiado $(42,2 \%)$. A forma mais comum de exposição foi a mordida de animais (88\%). O aumento no número de surtos de raiva ocorridos entre 20072011 indica a necessidade de desenvolver intervenções orientadas em especial para as pessoas nas regiões de alto risco, que visem melhorar as condições de vigilância e controle da raiva (ou da doença).

Palavras-chave: mordidas, vigilância, raiva, controle e prevenção, transmissão, Colômbia

\section{CARACTERIZACIÓN DE LAS EXPOSICIONES RÁBICAS EN COLOMBIA, 2007- 2011}

\section{RESUMEN}

\footnotetext{
${ }^{1}$ Universidad de Antioquia, Grupo de demografía y salud, Colombia.

${ }^{2}$ Florida International University.
} 
El objetivo de este estudio fue describir las exposiciones rábicas en Colombia y sus perfiles poblacionales, usando como fuente de información secundaria los datos reportados al Sistema de Vigilancia - Sivigila durante el periodo 2007-2011. Los casos de exposición rábica están categorizados en no exposición, exposición leve y exposición grave. Se observó incremento del evento durante 2007 (8.7\%) a 2011 (31.5\%). En Casanare el 31,4\% de los casos fueron clasificados como no exposición, en Arauca 86,7\% fueron exposiciones leves y Vaupés reporto el $88,5 \%$ de exposiciones graves. El evento fue más frecuente en hombres $(56,3 \%)$ y en régimen subsidiado $(42,2 \%)$. La mordedura fue la agresión más reportada (88\%). El aumento en el número de casos hace necesaria la evaluación de las actividades realizadas enfocándolas a los grupos con mayor riesgo y vulnerabilidad a las exposiciones rábicas, en aras de mejorar impacto y efectividad.

Palabras clave: Mordeduras de animales, vigilancia, rabia, control y prevención, trasmisión, Colombia

\section{INTRODUCTION}

In most countries of the world where rabies is endemic, surveillance of rabies infections in humans is carried out using different strategies such as detection of people in close contact with potential transmitters of the disease (1-6). Especially, as rabies is spread through close contact with infectious material, usually saliva, bites or scratches of infected animals (7).

Rabies is considered as one of the most frequently reported events in surveillance systems of infectious diseases $(5,8,9)$. With about 40,000 people exposed to rabies in the Unites States in 1998, it became one of the most important public health concerns in Northern America (10). In Olinda, Brazil, 7,062 exposures were reported to rabies between 2002 and 2006 showing an annual increase of events alerting health authorities as the disease became endemic most likely due to insufficient treatment (11). Guatemala reported 13,262 bites by animals exposed to rabies with $8 \%$ of the cases leading to death (12). Close to 7000 rabies consultations were made in the first half of 2005 in Santiago de Chile by victims of animal bites (13). Generally, those reports are a underestimation of the actual numbers as many victims of animal bites do not seek health-care services and treat their injuries according to their best knowledge at home.

Whereas some countries in the Americas such as the above mentioned ones have wellestablished surveillance system providing information on rabies events, little has been published about the characteristics of rabies exposure in Colombia. In order to provide relevant scientific information for political decision-makers in health-care, it is important to study the burden of rabies exposures and its most important underlying risk factors to protect the local population and to implement preventive measures.

The aim of this study was to describe the characteristics of the cases exposed to rabies in the Colombian population during 2007-2011.

\section{MATERIALS AND METHODS}

\section{Material}

This descriptive study used secondary data available on cases exposed to rabies notified to the national surveillance system (SIVIGILA) during 2007-2011. All in all, 217.478 cases were reported during the study period. As the structure of SIVIGILA has been changed during the study period, the data used in this study was manually revised to unify the information of the old and new data collecting system. Thus, the available information was combined into a single database. Cases with missing information on one or more variables used in this analysis 
were excluded. In addition, people with reported age of more than 44 years above the average life-expectancy of the Colombian population were excluded.

Methods

An event of rabies exposure collected by SIVIGILA is defined as a contact between a potentially infected animal and a human being (7). The cases of rabies exposure are categorized in the surveillance system according to no-risk exposure, low-risk exposure and high-risk exposure. In addition to the geographical site of the potential rabies contact, SIVIGILA collects information on characterization of the exposure, applied treatment and monitoring of potential rabies victims.

Data analysis

The data was analyzed using Excel software PASW statistics $18 \circledR, 7$ and Epi Info XLSTAT. Continuous variables are presented using measures of central tendency (mean, standard deviation) whereas frequencies are used for categorical variables. The overall prevalence of rabies exposure cases per 1,000 populations was calculated for the total number of cases and for no-risk, low-risk and high-risk exposure notified events. In the geographical maps of reported rabies cases relative frequencies and percentiles are presented.

Ethical considerations

As this study did not contain information identifying the individuals of the reported cases and used only secondary data, no permission of an ethical committee was needed according to the Colombian regulation.

\section{RESULTS}

The mean age of people exposed to rabies was 26 years ( $\mathrm{SD}=24.2$ years). The prevalence of no-risk exposure (54.8\%; 95\% CI 54.3-55.2\%), low-risk exposures $(56.6$; $95 \%$ CI \% 56.3-56.8) and high-risk exposure (57.6; 95\% CI 56.9-58.2\%) was higher in men compared to women. The average age of the notified cases in the high-risk exposure group (25.4 years, 95\% CI 25.2-25.8) was statistically significantly lower than the one observed in the low-risk exposure (26.5 years; 95\% CI 26.3-26.6) and no-risk exposure groups (26.7 years; 95\% CI 26.5-26.9).

During the five years of this analysis, 217618 cases of exposure to rabies were reported (Table 1). There was an increase in notified events of rabies exposure from $8.7 \%$ in 2007 to $31.5 \%$ in 2011 . The majority of rabies exposure cases were male (56\%; 95\% CI 55.9-56.7\%) and three out of four cases were registered in the major cities of the provinces $(75.5 \%$; $95 \%$ CI 75.3-75.6\%). However, there was no difference in the rate of notified rabies exposure events between the urban $(4.8 / 1,000)$ and rural $(4.8 / 1,000)$ areas. The percentage of notified cases involving people belonging to the state-subsidized health-insurance scheme was (42.2\%; 95\% CI 41.9-42.5\%), whereas the frequency of cases of individuals who pay a monthly fee for their health-care coverage (contributive system) was $41.3 \%$ (95\% CI 41.041.6). This prevalence was rather stable during the period of data analysis with the exception of the year 2008 when the frequency of reported cases was higher in the contributive healthcare regime.

Table 1. Sociodemographic characteristics of rabies exposure events in Colombia during 2007-2011. 


\begin{tabular}{|c|c|c|c|c|c|c|c|c|c|c|c|c|c|}
\hline \multirow[t]{2}{*}{ Variable } & & \multicolumn{2}{|c|}{2007} & \multicolumn{2}{|c|}{2008} & \multicolumn{2}{|c|}{2009} & \multicolumn{2}{|c|}{2010} & \multicolumn{2}{|c|}{2011} & \multicolumn{2}{|c|}{ Total } \\
\hline & & n & $\%$ & n & $\%$ & n & $\%$ & n & $\%$ & n & $\%$ & n & $\%$ \\
\hline \multicolumn{2}{|l|}{ Reporting year } & \multicolumn{2}{|c|}{19,012} & \multicolumn{2}{|c|}{41,215} & \multicolumn{2}{|c|}{41,044} & \multicolumn{2}{|c|}{47,737} & \multicolumn{2}{|c|}{68,610} & \multicolumn{2}{|c|}{217618} \\
\hline Sex & Male & 10798 & 56.8 & 23288 & 56.5 & 23393 & 57.0 & 26761 & 56.1 & 38308 & 55.9 & 122548 & 56.3 \\
\hline \multirow{3}{*}{ Area of residence } & Urban & 13038 & 68.6 & 32315 & 78.4 & 31547 & 76.9 & 36093 & 75.6 & 51250 & 74.8 & 164243 & 75.5 \\
\hline & Semi-urban & 3670 & 19.3 & 3718 & 9.0 & 3507 & 8.5 & 3859 & 8.1 & 5796 & 8.5 & 20550 & 9.4 \\
\hline & Rural & 2304 & 12.1 & 5182 & 12.6 & 5990 & 14.6 & 7767 & 16.3 & 11512 & 16.8 & 32755 & 15.1 \\
\hline \multirow{2}{*}{ Health insurance } & Contributory & 7171 & 37.7 & 16979 & 41.2 & 16646 & 40.6 & 19833 & 41.6 & 29204 & 42.6 & 89833 & 41.3 \\
\hline & Subsidized & 7325 & 38.5 & 15933 & 38.7 & 16956 & 41.3 & 20719 & 43.4 & 30861 & 45.1 & 91794 & 42.2 \\
\hline \multirow{3}{*}{ Ethnicity } & Indigenous & 429 & 2.3 & 769 & 1.9 & 1070 & 2.6 & 896 & 1.9 & 1211 & 1.8 & 4375 & twenty \\
\hline & Afro-Colombian & 2403 & 12.6 & 3290 & 8.0 & 2967 & 7.2 & 2385 & fifty & 2807 & 4.1 & 13852 & 6.4 \\
\hline & Other & 16048 & 84.4 & 36419 & 88.4 & 36392 & 88.7 & 43877 & 92.0 & 64171 & 93.7 & 196907 & 90.5 \\
\hline \multirow{2}{*}{ Population group } & Other population groups & 18851 & 99.2 & 40982 & 99.4 & 40813 & 99.4 & 47502 & 99.6 & 68210 & 99.7 & 216358 & 99.5 \\
\hline & Displaced people & 92 & 0.5 & 149 & 0.4 & 170 & 0.4 & 140 & 0.3 & 170 & 0.2 & 721 & 0.3 \\
\hline Case Type & $\begin{array}{l}\text { Confirmed by clinical } \\
\text { diagnostics }\end{array}$ & 15201 & 80.0 & 30756 & 74.6 & 41044 & 100 & 47699 & 99.9 & 68474 & 99.8 & 203174 & 93.4 \\
\hline Hospitalization & No hospitalization & 18547 & 97.6 & 40264 & 97.7 & 40102 & 97.7 & 46500 & 97.4 & 66979 & 97.7 & 212392 & 97.6 \\
\hline
\end{tabular}

Figure 1 shows the number of cases identified per 1000 population in each of the provinces of Colombia according to percentile. The largest percentage of notifications received by SIVIGILA was from the district of Bogotá (17\%) followed by the provinces of Valle del Cauca (14\%), Cundinamarca (7.5\%), Antioquia (6.2\%), Santander (5.7\%) and Huila $(4.8 \%)$. The average reporting rate of rabies exposure for entire Colombia was 4.8 per 1,000 inhabitants. The provinces with the highest reported events of rabies exposure per 1000 people were Vaupés (12.3), Arauca (11.4) and Huila (9.8). The highest rate of no-risk exposure was recorded in the provinces of Casanare (31.4), Sucre (26.3) and Tolima (25.9). Whereas the highest rate of low-risk exposure was 86.7/1000 in Arauca, the province of Vaupés in the Amazon region reported the highest rate of high-risk exposure cases $(88.5 / 1000)$.

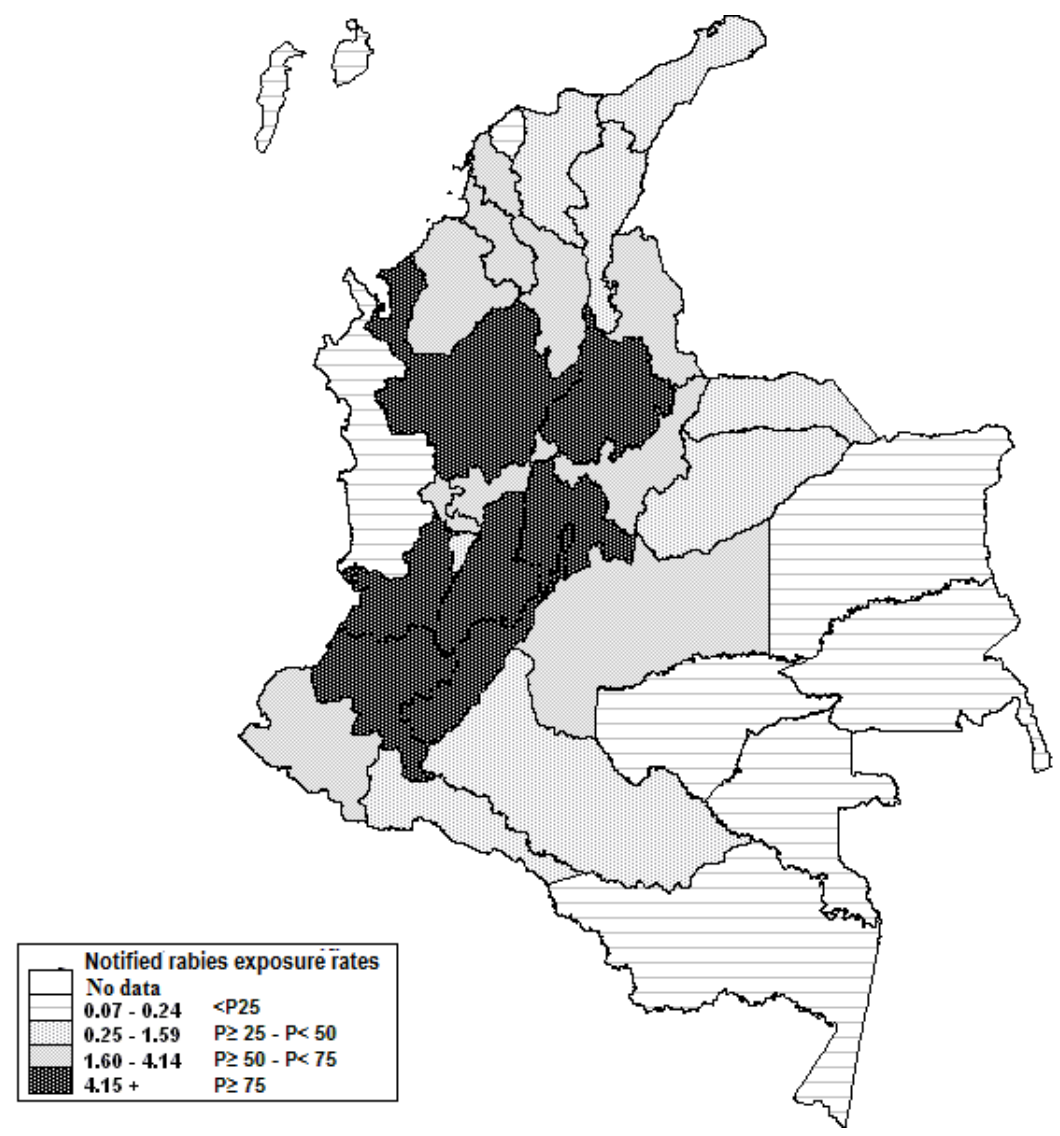

Figure 1. Rates of high-risk rabies exposure according to province in Colombia during 20072011. 
Table 2 presents the characteristics of the rabies exposure cases reported to SIVIGILA. About $98 \%$ of cases did not require hospitalization and the victims were attended in outpatient clinics. Less than $1 \%$ of the cases in rabies exposure victims resulted in death $(n=8)$ during the study period. Animal bites were the most common type of rabies exposure contact accounting for $88 \%$ of all reported cases. In addition, half of the bite injury occurred in the lower legs $(51.5 \%)$, whereas wounds in upper extremities were registered in one out of five cases $(20.2 \%)$. The most prevalent animal responsible for the rabies exposure incident was the $\operatorname{dog}(84.8 \%)$. Most of the animals showed no signs of rabies infection at the time of exposure and were left alive after an observation period. Most of the cases (71\%) recorded were classified as low-risk. The corresponding prevalence of no-risk and high-risk exposure were $19.5 \%$ and $9.5 \%$, respectively.

Table 2. Characteristics of rabies exposure wounds in Colombia during 2007-2011.

\begin{tabular}{|c|c|c|c|c|c|c|c|c|c|c|c|c|c|}
\hline \multirow[t]{2}{*}{ Variable } & & \multicolumn{2}{|c|}{2007} & \multicolumn{2}{|c|}{2008} & \multicolumn{2}{|c|}{2009} & \multicolumn{2}{|c|}{2010} & \multicolumn{2}{|c|}{2011} & \multicolumn{2}{|c|}{ Total } \\
\hline & & n & $\%$ & n & $\%$ & n & $\%$ & n & $\%$ & n & $\%$ & n & $\%$ \\
\hline \multirow{4}{*}{$\begin{array}{l}\text { Type of } \\
\text { lesion }\end{array}$} & Bite & 16830 & 89.4 & 35362 & 86.8 & 36117 & 88.8 & 42230 & 88.7 & 61074 & 89.3 & 191613 & 88.6 \\
\hline & Scratch & 1742 & 9.3 & 4825 & 11.8 & 3986 & 9.8 & 4645 & 9.8 & 6702 & 9.8 & 21900 & 10.1 \\
\hline & Lick & 73 & 0.4 & 113 & 0.3 & 99 & 0.2 & 141 & 0.3 & 155 & 0.2 & 581 & 0.3 \\
\hline & $\begin{array}{l}\text { Saliva contact with open } \\
\text { skin or mucosa }\end{array}$ & 97 & 0.5 & 241 & 0.6 & 281 & 0.7 & 369 & 0.8 & 229 & 0.3 & 1217 & 0.6 \\
\hline Injury type & Unique & 12482 & 66.3 & 27430 & 67.4 & 26962 & 66.3 & 31747 & 66.7 & 45469 & 66.5 & 144090 & 66.6 \\
\hline \multirow{2}{*}{$\begin{array}{l}\text { Depth of } \\
\text { wound }\end{array}$} & Superficial & 15514 & 82.4 & 34007 & 83.7 & 33332 & 81.9 & 38941 & 81.8 & 56488 & 82.6 & 178282 & 82.5 \\
\hline & Deep & 3317 & 17.6 & 6613 & 16.3 & 7344 & 18.1 & 8668 & 18.2 & 11864 & 17.4 & 37806 & 17.5 \\
\hline \multirow{5}{*}{$\begin{array}{l}\text { Anatomic } \\
\text { site of injury }\end{array}$} & Head, face or neck & 2666 & 14.2 & 5135 & 12.6 & 5305 & 13.0 & 5977 & 12.6 & 8773 & 12.9 & 27856 & 12.9 \\
\hline & Hand, finger & 3374 & 17.9 & 8881 & 21.8 & 8457 & 20.8 & 9782 & 20.5 & 13236 & 19.4 & 43730 & 20.2 \\
\hline & Trunk & 1072 & 5.7 & 2385 & 5.9 & 2552 & 6.3 & 2751 & 5.8 & 4067 & 6.0 & 12827 & 5.9 \\
\hline & Superior member & 3327 & 17.7 & 7305 & 17.9 & 7717 & 19.0 & 9023 & 19.0 & 12622 & 18.5 & 39994 & 18.5 \\
\hline & Lower member & 9901 & 52.6 & 20571 & 50.5 & 20837 & 51.2 & 24537 & 51.5 & 35401 & 51.8 & 111247 & 51.5 \\
\hline \multicolumn{14}{|c|}{ Information on animal contact } \\
\hline \multirow{3}{*}{$\begin{array}{l}\text { Species } \\
\text { aggressor }\end{array}$} & Dog & 17170 & 90.3 & 33027 & 80.1 & 33695 & 82.1 & 40583 & 85.0 & 60116 & 87.6 & 184591 & 84.8 \\
\hline & Cat & 834 & 4.4 & 5318 & 12.9 & 4011 & 9.8 & 4862 & 10.2 & 6674 & 9.7 & 21699 & 10.0 \\
\hline & Pork & 585 & 3.1 & 202 & 0.5 & 97 & 0.2 & 101 & 0.2 & 116 & 0.2 & 1101 & 0.5 \\
\hline \multirow{3}{*}{$\begin{array}{l}\text { Presence of } \\
\text { rabies } \\
\text { symptoms }\end{array}$} & With rabies symptoms & 763 & 4.1 & 1275 & 3.2 & 1225 & 3.1 & 972 & twenty & 650 & 1.0 & 4885 & 2.3 \\
\hline & No rabies symptoms & 10630 & 56.5 & 24583 & 60.8 & 25194 & 63.2 & 32105 & 67.6 & 51896 & 76.4 & 144408 & 67.3 \\
\hline & Unknown & 7437 & 39.5 & 14548 & 36.0 & 13437 & 33.7 & 14424 & 30.4 & 15405 & 22.7 & 65251 & 30.4 \\
\hline \multirow{3}{*}{$\begin{array}{l}\text { Exposure } \\
\text { Type }\end{array}$} & Low-risk & 0 & 0.0 & 0 & 0.0 & 0 & 0.0 & 10257 & 21.7 & 31736 & 46.9 & 41993 & 19.5 \\
\hline & Moderate risk & 16613 & 88.2 & 36546 & 89.6 & 36368 & 89.4 & 32351 & 68.3 & 30819 & 45.6 & 152697 & 70.9 \\
\hline & High-risk & 2217 & 11.8 & 4207 & 10.3 & 4265 & 10.5 & 4738 & 10.0 & 5098 & 7.5 & 20525 & 9.5 \\
\hline
\end{tabular}

Most of the rabies exposure victims were advised to wash the wound immediately with soap and water (Table 3). Anti-rabies serum (immunoglobulin) was administered in $8.1 \%$ of cases and a $28 \%$ of bite victims were vaccinated after the event. Only a small percent of the treated individuals reported adverse reactions to the treatment $(5.3 \%)$. It was found that 8,504 of the cases classified as high-risk exposure (41.4\%) was applied with an anti-rabies serum. The corresponding frequency of anti-rabies serum application in the low-risk group and norisk group were $1.3 \%(\mathrm{n}=1941)$ and $0.3 \%(\mathrm{n}=119)$, respectively. Furthermore, a rabies vaccination was given in $55.4 \%(\mathrm{n}=11.370)$ of the high-risk exposure cases, $31.1 \%$ $(n=47.484)$ of the low-risk events and in $2.5 \%(n=1.057)$ of the no-risk exposure cases. The majority of animals possible infected with rabies were alive after the observation period (94.7\%). In most of the cases the animal's health was monitored at home (96.5\%).

Table 3. Characteristics of anti-rabies treatment posterior to exposure in Colombia during 2007-2011. 


\begin{tabular}{|c|c|c|c|c|c|c|c|c|c|c|c|c|c|}
\hline \multirow[t]{2}{*}{ Variable } & & \multicolumn{2}{|c|}{2007} & \multicolumn{2}{|c|}{2008} & \multicolumn{2}{|c|}{2009} & \multicolumn{2}{|c|}{2010} & \multicolumn{2}{|c|}{2011} & \multicolumn{2}{|c|}{ Total } \\
\hline & & n & $\%$ & n & $\%$ & n & $\%$ & $\mathbf{N}$ & $\%$ & $\%$ & n & $\%$ & n \\
\hline \multicolumn{14}{|c|}{ Pat history of immunization } \\
\hline Anti-rabies serum & Not applied & 17144 & 91.0 & 34661 & 85.0 & 35028 & 86.2 & 41854 & 88.0 & 61900 & 90.7 & 190587 & 88.2 \\
\hline Rabies vaccine & Not applied & 16425 & 87.2 & 33225 & 82.1 & 33864 & 84.5 & 40603 & 85.4 & 60397 & 88.5 & 184514 & 85.7 \\
\hline \multicolumn{14}{|l|}{ Current treatment } \\
\hline $\begin{array}{l}\text { Wound care using water } \\
\text { and soap }\end{array}$ & if & 17510 & 93.0 & 37950 & 93.9 & 37459 & 94.0 & 45129 & 94.8 & 65581 & 96.0 & 203629 & 94.7 \\
\hline Wound suturing & Not applied & 17137 & 91.0 & 37868 & 93.1 & 37229 & 92.1 & 43843 & 92.1 & 63352 & 92.7 & 199429 & 92.4 \\
\hline Anti-rabies serum & Not applied & 18544 & 99.1 & 8615 & 91.6 & 4230 & 70.6 & 24977 & 88.6 & 63382 & 93.1 & 119748 & 91.9 \\
\hline Vaccination & Not applied & 17460 & 92.7 & 36055 & 89.2 & 32220 & 80.8 & 28799 & 60.6 & 40227 & 58.9 & 154761 & 72.0 \\
\hline \multicolumn{14}{|l|}{ Case tracking } \\
\hline \multirow{2}{*}{$\begin{array}{l}\text { Type of adverse reactions } \\
\text { to application of anti- } \\
\text { rabies serum }\end{array}$} & None & 2 & $5 o^{\prime}$ clock & 350 & 92.8 & 1526 & 96.6 & 2018 & 94.0 & 2069 & 94.3 & 5965 & 94.7 \\
\hline & Local & 2 & $5 \mathrm{o}^{\prime}$ clock & 24 & 6.4 & 51 & 3.2 & 119 & 5.5 & 111 & 5.1 & 307 & 4.9 \\
\hline \multirow{3}{*}{$\begin{array}{l}\text { Adverse reactions to the } \\
\text { application of the vaccine } \\
\text { or serum }\end{array}$} & None & 1237 & 95.0 & 2716 & 85.4 & 4954 & 85.1 & 9395 & 94.9 & 11406 & 93.5 & 29708 & 91.7 \\
\hline & Local & 56 & 4.3 & 448 & 14.1 & 854 & 14.7 & 477 & 4.8 & 749 & 6.1 & 2584 & 8.0 \\
\hline & Systemic & 9 & 0.7 & 18 & 0.6 & 10 & 0.2 & 28 & 0.3 & 48 & 0.4 & 113 & 0.3 \\
\hline \multirow[b]{2}{*}{ Suspension of treatment } & Not suspended & 1070 & 82.8 & 2093 & 71.3 & 4135 & 81.0 & 6874 & 67.6 & 8158 & 66.6 & 22330 & 70.3 \\
\hline & $\begin{array}{l}\text { Due to medical } \\
\text { order }\end{array}$ & 222 & 17.2 & 683 & 23.3 & 792 & 15.5 & 1414 & 13.9 & 2023 & 16.5 & 5134 & 16.2 \\
\hline $\begin{array}{l}\text { Place of patient } \\
\text { monitoring }\end{array}$ & Home & 11543 & 98.0 & 19557 & 97.5 & 15800 & 96.6 & 17704 & 96.4 & 21236 & 94.7 & 85840 & 96.5 \\
\hline \multirow{3}{*}{$\begin{array}{l}\text { Condition of the animal } \\
\text { after observation }\end{array}$} & Healthy & 11503 & 98.0 & 19590 & 93.9 & 15959 & 92.5 & 17897 & 94.2 & 21315 & 95.9 & 86264 & 94.7 \\
\hline & Sick & 204 & 1.7 & 365 & 1.7 & 313 & 1.8 & 365 & 1.9 & 577 & 2.6 & 1824 & twenty \\
\hline & Dead & 36 & 0.3 & 914 & 4.4 & 979 & 5.7 & 736 & 3.9 & 341 & fifteen & 3006 & 3.3 \\
\hline
\end{tabular}

\section{DISCUSSION}

This study found an annual increase in reported cases of rabies exposure with a high number of cases in urban centers as expected due to the higher population density. However, the highest prevalence of high-risk exposure was observed in Vaupes whereas Casanare reported the highest moderate-risk rabies exposure prevalence. The prevalence of rabies exposure notifications did not differ between urban and rural sites or health-insurance regime even though the subsidized scheme had a slightly higher prevalence.

In line with other studies, most notified rabies exposures cases occur in young people, with a higher proportion of notified cases in children (13-15). This may be due to the fact that children are more affected by their smaller body size and may be more exposed to animal bites due to their behavior or reactions in situations involving animal attacks (13). Consistent with a previous study, notified rabies exposure events were most prevalent in men in younger age-groups (9).

In line with previous studies, in Colombia, the most common reason of rabies exposure were dog bites (13,16-19).

Every second application of anti-rabies treatment was handled incorrectly, especially in cases of high-risk or moderate risk exposure. This may be due to lack of training in using the national rabies exposure protocol (7) and clinical management guidelines. In disagreement with the national rabies treatment protocol, in many cases of low-risk exposure an anti-rabies serum was given to the exposed individuals leading to unnecessary additional costs for the surveillance and national health-care system.

Another possibility is that only some of the rabies treatment procedures were registered in the surveillance system, thus, providing a sub estimation of the real treatment applied $(7,20,21)$.

The majority of notified rabies exposure cases were subsequently clinically tested by laboratory tests to rule out a possible infection according to the national rabies protocol. Despite the national guideline implying that the results of the clinical rabies tests have to be received within four week after the exposure, the clinical information sent to the register was often delayed or not received at all resulting in incomplete information of the follow-up rabies exposure cases in the surveillance system (7). Therefore, some cases are classified in the data base as confirmed by laboratory tests, suspected cases or probable rabies infection cases.

Similar to the findings of Beltran et al. (22) reporting that the official rabies treatment protocol provided by WHO is rarely followed, it is of concern that bites injuries caused by 
wild animals that are generally classified as high-risk exposure cases, were not immediately treated by vaccination or anti rabies serum as indicated in the Colombian clinical guidelines. This is also reflected in the low percentages of hospitalization following rabies exposure.

In general, little information was available on the follow-up of the patients treated after the rabies exposure. It is important to improve the Colombian surveillance system and to track patients that have received anti rabies serum or vaccination in order to explore the treatment outcome or whether any complications of the treatment were reported. A similar concern has been observed in other studies as well $(22,23)$. In the USA, for instance, there was no evidence of any anti-rabies treatment initiated after exposure during 1980 and 1998 (24). Furthermore, in our study, the multiple correspondence analyses showed misclassification of several cases of rabies exposure. While high-risk exposures were classified in the majority of cases correctly according to the established indicators, several problems were observed in the exposure cases classified as moderate-risk or low-risk exposures where the labeling of cases was not done according to the official indicators of the surveillance guidelines. This misclassification of rabies exposure cases shows the need to thoroughly evaluate all components of the surveillance system to improve the accuracy of its information on each level and to guarantee that the information of the system is entered correctly by the people feeding the register.

Naturally, our study had some limitations. The notifying system for cases of rabies exposure has changed during the reporting period of our study. Thus, the number of cases notified in the earlier years may be underestimated. Moreover, it has been estimated that only $20 \%$ of the rabies exposure cases may be notified (24). Furthermore, some cases may be registered more than once in the system as it was not possible to exclude those cases from the data analysis. Due to ethical reasons, all the information on personal identity of the patients was removed before the study group was given the permission to analysis the data. However, this may only affect a very small percentage of the cases and, thus, only has a minor impact on the results of this study.

In conclusion, there is a need to implement educational intervention to reduce exposure to rabies especially in the provinces with a high prevalence of high-risk rabies exposure events. Ideally, these interventions may be led by local and national health-authorities. Successful interventions may reduce the costs of the management of people exposed to rabies. In addition, we recommend to study in more details why certain ethic groups show a higher exposure to rabies than other population groups. Moreover, in-depth analysis should be carried out on all levels to assess the flaws of the surveillance system in regard lack of monitoring of patients treated after rabies exposure and how to reduce the misclassification of rabies cases in order to strengthen the rabies surveillance system in Colombia.

\section{REFERENCES}

1. Organización Panamericana de la Salud. Ministerio de Salud. Manual de normas y procedimientos para la vigilancia prevención y control de la rabia [Internet]. Buenos Aires: OPAS; 2007 [cited 22 Oct 2013]. Available from: http://www.paho.org/arg/publicaciones/publicaciones\%20virtuales/cdmanualRabia/comite. html.

2. Secretaría de Salud. Manual de procedimientos estandarizados para la vigilancia epidemiológica de la rabia en humano [Internet]. Cidade do Mexico: Secretaría de Salud; 2012 [cited 2013 Jan 11]. Available from: http://www.epidemiologia.salud.gob.mx/doctos/infoepid/vig_epid_manuales/23_2012_Ma nual_RabiaHumano_4dic12.pdf. 
3. Townsend SE, Lembo T, Cleaveland S, Meslin FX, Miranda ME, AAG Putra et al. Surveillance guidelines for disease elimination: a case study of canine rabies. Comp Immunol Microbiol Infect Dis. 2013;36(3):249-61.

4. Johnson N, Aréchiga-Ceballos N, Aguilar-Setien A. Vampire bat rabies: ecology, epidemiology and control. Viruses. 2014;6(5):1911-28.

5. Vigilato MAN, Clavijo A, Knobl T, Silva HMT , Cosivi O, Schneider MC, et al. Progress towards eliminating canine rabies: policies and perspectives from Latin America and the Caribbean. Philos Trans R Soc Lond B Biol Sci. 2013;368(1623):20120143.

6. Oviedo-Pastrana ME, Oliveira CSF, Capanema RO, Nicolino RR, Oviedo-Socarras TJ, Haddad JPA. Trends in animal rabies surveillance in the endemic state of Minas Gerais, Brazil. PLoS Negl Trop Dis. 2015;9(3):e0003591.

7. Instituto Nacional de Salud (CO). Sistema nacional de vigilancia en salud pública sivigila protocolo de vigilancia de rabia [CD -ROM]. Bogotá: El Instituto; 2012.

8. Hampson K, Coudeville L, Lembo T, Sambo M, Kieffer A, Attlan M, et al. Estimating the global burden of endemic canine rabies. PLoS Negl Trop Dis. 2015;9(4):e0003709.

9. Yao H-W, Yang Y, Liu K, Li X-L, Zuo S-Q, Sun R-X, et al. The spatiotemporal expansion of human rabies and its probable explanation in Mainland China, 2004-2013. PLoS Neg1 Trop Dis. 2015;9(2):e0003502.

10. Blanton JD, Manangan A, Manangan J, Hanlon CA, Slate D, Rupprecht CE. Development of a GIS-based, real-time Internet mapping tool for rabies surveillance. Int J Health Geogr. 2006;5:47.

11. Dantas-Torres F, Oliveira-Filho E. Human exposure to potential rabies virus transmitters in Olinda, State of Pernambuco, between 2002 and 2006. Rev Soc Bras Med Trop. 2007;40:617-21.

12. Forde T. Rabies surveillance and control in Guatemala [Internet]. 2009 [cited 2013 Jan 11]. Available from: http://www.medvet.umontreal.ca/infoGen/international/giv/wordpress/wpcontent/uploads/2011/01/rapport_guatemala_2009.pdf.

13. Jofré ML, Perret PC, Abarca VK, Solari GV, Olivares CR, López PJ. Recomendaciones para el manejo de mordeduras ocasionadas por animales Rev Chil Infectol [Internet]. 2006 [cited 2013 Oct 22];23(1):20-34. Available from: http://www.scielo.cl/pdf/rci/v23n1/art02.pdf.

14. Instituto Nacional de Salud (CO). Sistema nacional de vigilancia en salud pública sivigila - protocolo de vigilancia de rabia [CD -ROM]. Bogotá; El Instituto; 2009.

15. Bourhy H, Dautry-Varsat A, Hotez PJ, Salomon J. Rabies, still neglected after 125 years of vaccination. Plos Neg1 Trop Dis. 2010;4:839. 
16. Presutti RJ. Prevention and treatment of dog bites. Am Fam Physician. 2001;15:1567-72.

17. Bregman B, Slavinski S. Using emergency department data to conduct dog and animal bite surveillance in New York City, 2003-2006. Public Health Rep. 2012;127:195-201.

18. Takayama N. Rabies: a preventable but incurable disease. J Infect Chemother. 2008;14:814.

19. Morgan M, Palmer J. Dog bites. BMJ. 2007;334:413-7.

20. Chang Y, McMahon J, Hennon D, LaPorte R, Coben J. Dog bite incidence in the city of Pittsburgh: a capture-recapture approach. Am J Public Health. 1997;87:1703-5.

21. Dias R, Rangel D, Oliveira L, Bittencourt C, Sangiovanni J. Motivos de abandono do tratamento antirrábico humano pós-exposição em Porto Alegre (RS, Brasil). Cienc Saude Colect. 2011;16:537-46.

22. Saad C, Toro G, Martinez M, Diaz A. Rabia: guia practica para la atencion integral de personas agredidas por un animal potencialmente transmisor de Rabia. 1a ed. Bogotá: Editorial Vasa; 2009.

23. Beltran C, Muñoz M, Sierra Z, Rueda J, Ulloa A. Análisis de situación del sistema de vigilancia en salud pública de exposición rábica 2008. Inf Quinc Epidemiol Nac. 2011;16:31-4.

24. Noah DL, Drenzek CL, Smith JS, Krebs JW, Orciari L, ShaddockJ, et al. Epidemiology of human rabies in the United States, 1980 to 1996. Ann Intern Med. 1998;128:922-30.

Recebido em: Aceito em: 